\title{
ЗАСОБИ МАСОВОЇ ІНФОРМАЦІЇ ЯК СУБ’ЄКТИ ДОСЯГНЕННЯ СУСПІЛЬНО-ДЕРЖАВНОГО КОНСЕНСУСУ: АНАЛІЗ ЗАКОНОДАВЧИХ ТА ДОКТРИНАЛЬНИХ ПІДХОДІВ
}

\begin{abstract}
Анотація. У статті представлено результат теоретичного осмислення поняття засобів масової інформації як суб'ектів досягнення суспільно-державного консенсусу на основі аналізу законодавчих та доктринальних підходів. Розглянуто парадигму інформаційної співпраці органів державної влади і засобів масової інформації, що створюе можливість для вдосконалення законодавчого підгрунтя функщіонування засобів масової інформації в демократичному суспільстві. У результаті критичного аналізу визначень засобу масової інформації у сучасній наущі, сформульовано авторську дефініцію «засобу масової інформації» як юридичної особи (організації), діяльність якої спрямована на виробництво і швидкісну передачу інформаційної продукції публічного характеру для необмеженої кількості споживачів, яка функціонуе шляхом створення та розповсюдження будь-яким законним способом донесення інформації до споживачів (аудиторії).
\end{abstract}

Ключові слова: засоби масової інформації, інформаційне суспільство, інформаційний простір, мас-медіа, засоби масової комунікації, інформаційне законодавство.

Sikorskyi Andrii

Kyiv International University

\section{MASS MEDIA AS THE SUBJECTS IN ARRIVING STATE-PUBLIC CONSENSUS: ANALYSIS OF LEGISLATIVE AND DOCTRINAL APPROACHES}

Summary. The article presents the result of theoretical comprehending the concept of mass media as subjects of reaching public and state consensus based on the analysis of legislative and doctrinal approaches. It is substantiated that the Ukrainian regulatory framework regarding media activity is characterized by the chaotic separation of some electronic media - television and radio, as audiovisual media, and the complete lack of regulatory regulation of modern media - the Internet. Ukraine does not adequately ensure the constitutional and legal regulation of the media sphere, first of all, through the slow adaptation and reform of the entire legal system, which does not correspond to the tendencies of world globalization and therefore is ineffective. An analysis of scientific approaches to the formation of communicative paradigms in the context of the the information society's formation has shown that the effectiveness of public administration depends to a large extent on the level of interaction, openness and transparency of public authorities in the information environment. At the same time, the elimination of the existing information and communication problems is related to the identity between the objective and subjective factors of public administration, where information interaction and Ukraine's entry into the world information space play an important role. Thus, there is a growing need to develop new information relations, to expand the possibilities for the introduction and use of information and communication technologies in management activities. It requires a scientific grounding of the developed approaches from the point of view of the public administration theory. The paradigm of informational cooperation between government bodies and the media is considered, which provides an opportunity for improving the legislative framework for the functioning of the media in a democratic society. As a result of a critical analysis of the definitions of mass media in modern science, the author's definition of "mass media" was formulated as a legal entity (organization) whose activities are aimed at the production and high-speed transmission of information products of a public nature for an unlimited number of consumers, which functions by creating and distributing by any legal means of delivering information to consumers (audience).

Keywords: mass media, information society, information space, mass media, mass media, information legislation.

$\Pi$ остановка проблеми. Початок нового тисячоліття стае часом значних перетворень у всіх сфрерах суспільного життя сучасних держав. Якісні зміни захопили не лише матеріальне виробництво, ринкові відносини, а й інформаційну сферу суспільства, що проявляеться в подальшому зростанні інформаційних потреб у кожної людини. Однією з таких е потреба в інформації щодо діяльності органів влади різних рівнів. Між тим сьогодні уявлення людей про світ і процеси, що відбуваються в ньому, значною мірою формуються засобами масової інформації. Інформатизація веде до створення единого інформаційного простору, у рамках якого здійснюеться споживання інформації, їі виробництво і зберігання, взаємообмін між різними суб’ектами цього простору. Означені зміни потребують наукового осмислення, зокрема в адміністративно-правовій площині, аби стати теоретичним підгрунтям для розв'язання нагальних потреб організації діалогу органів державної влади та засобів масової інформації з метою повноцінного входження України до світової інформаційної спільноти. Тому питання визначення поняття засобів масової інформації як засіб досягнення суспільнодержавного консенсусу є актуальним, потребуе ретельного аналізу та фундаментального дослідження. 
Аналіз останніх досліджень і публікацій. Правові аспекти фрункціонування інформаційного простору, ЗМІ та їх складових досліджували І.В. Арістова, І.Л. Бачило, О.А. Баранов, Л.І. Біловус, К.І. Беляков, В.М. Брижко, А.В. Манойло, Р.А. Калюжний, В.О. Копилов, О.В. Логінов, О.В. Олійник, Р.С. Свистович, О.В. Соснін, О.М. Селезньова, В.С. Цимбалюк, Л.Є. Шиманський та інші. Їх напрацювання стали основою для подальшого наукового пізнання діяльності суб'єктів інформаційних та адміністративних правовідносин і розвитку понятійно-категоріального апарату. Однак на сьогодні недостатньо грунтовними е дослідження засобів масової інформації як одних зі стрижневих понять в законодавстві, а також дослідження ролі ЗМI в суспільно-державному діалозі.

Мета статті. Виходячи 3 цих міркувань, мета даної статті полягае в тому, щоб запропонувати результат теоретичного осмислення поняття засобів масової інформації як суб'ектів досягнення суспільно-державного консенсусу на основі аналізу законодавчих та доктринальних підходів.

Виклад основного матеріалу. В сучасних умовах можливості для реалізації прав громадян на інформацію та свободу слова значно розширилися, водночас суттево зросли потреби потенційно активної частини суспільства в інформаційній взаємодії як всередині країни, так і з зовнішнім світом. Провідну роль у забезпеченні свободи слова та права на інформацію відіграють засоби масової інформації - інститути громадянського суспільства, для яких інформаційна діяльність є головним завданням і фрормою існування.

Згідно зі статтею 10 Конвенції про захист прав людини і основоположних свобод [1], вільні й незалежні засоби масової інформації мають першочергову важливість для життя демократичного суспільства. Сучасні засоби масової інформації, передаючи значні обсяги інформації, впливають на сфрери роботи, побуту та дозвілля, формують суспільну думку та моделі поведінки. Враховуючи масштаб впливу сучасних засобів масової інформації на суспільство, держава зобов'язана контролювати їх діяльність. Це повинно відбуватися шляхом запровадження нормативно-правової бази, яка відповідатиме всім трансформаційним перевтіленням засобів масової інформації. Неминучий розвиток усіх медіа технологій призводить до полегшення процесу пошуку інформації, ï систематизації, накопичення та подальшого розповсюдження.

Ні на міжнародному, ні на національному рівні не прийнято єдиного підходу до розуміння ЗМІ, що зумовлено inter alia відсутністю однозначного розуміння журналістської діяльності. Зазначимо, що термін «засіб масової інформації» вперше з'явився у преамбулі статуту ООН з питань освіти, науки та культури (ЮНЕСКО) 1945 року [2].

У резолюції ПАРЕ 428 (1970) «Щодо декларації про засоби масової інформації та права людини» до ЗМІ віднесено друковані та інші засоби масової інформації [3], але зміст останніх не розкрито.

У рамках Заключного акта НБСЕ (1975 р.) до ЗМІ було віднесено друковані засоби, радіо, телебачення, кіно- та телеагентства (частина IV, гл. 2) [4]. У Конвенції ООН «Про між- народне право спростування» (1952р.) замість 3MI використовуеться термін «інформаційні агентства», який «означає будь-яку організацію в області друку, радіо, кіно, телебачення або телефотографіiі» [5].

Так, у Рекомендації Комітету міністрів Ради Європи державам-членам CM/Rec(2007)15 до 3МI належать: друковані медіа (газети, періодичні видання), медіа, які поширюють інформацію через електронні комунікаційні мережі, нелінійні медійні аудіовізуальні медійні послуги (відео на замовлення) [6]. У рамках ще одніеї рекомендації Комітету міністрів Ради Європи CM/Rec(2007)15 запропоновано максимально широкий підхід до розуміння ЗМI, який включає всіх учасників, пов'язаних з виробництвом та розповсюдженням серед потенційно великої кількості людей контенту (наприклад, інформації, аналізу, коментарів, думок, освіти, культури, мистецтва і дозвілля у друкованій, аудіо, візуальній, аудіовізуальній чи іншій формі), і способи застосування, спрямовані на те, щоб сприяти інтерактивним масовим комунікаціям (наприклад, у соціальних мережах) або іншій заснованій на контенті широкомасштабній інтерактивній діяльності (наприклад, ігри в режимі «он-лайн»), зберігаючи при цьому (у всіх цих випадках) редакційний контроль або нагляд над контентом [7].

Аналіз цього підходу дає підстави стверджувати, що ЗМІ - це будь-яка особа, відповідальна за періодичне створення та розповсюдження інформації (контенту), яка несе редакційну відповідальність, незалежно від засобів та технологій, що використовуються для передачі даних, якщо такі технології спрямовані на ï отримання значною частиною суспільства та можуть мати чіткий вплив на неї.

У рамках національного законодавства держав Європи також відсутній одноманітний підхід до розуміння категорії ЗМІ. Так, у законі Словенії про ЗМІ (ст. 2) визначено, що ними e «газети і журнали, послуги радіо і телебачення, електронні видання, телетекст та інші форми редакційно сформульованих програм, які виходять щодня або періодично через передачу письмових матеріалів, звукового або фотографічного доступу до громадськості», хоча при цьому не поширюються на державні друковані і аудіовізуальні ЗMI [8]. Проте в більшості країн не використовуеться уніфікований режим правового регулювання для всіх видів ЗМІ, а отже, відсутні едині засади їх правового регулювання. Так, у Швеції існують окремі закони про радіо і телебачення (2010 р.) [9].

Аналогічний підхід міститься також у законодавстві України. Існуе окремий закон, який визначає правовий статус друкованих засобів масової інформації (пресу) в Україні (1992р.) та регулюе діяльність «періодичних і таких, що продовжуються, видань, які виходять під постійною назвою, з періодичністю один і більше номерів (випусків) протягом року» [10] (ст. 1). Водночас функціонування телебачення і радіомовлення врегульовано Законом «Про телебачення і радіомовлення» (1993р.), яким, серед іншого, визначено, що «трансляція (телерадіотранслящія) - початкова передача, яка здійснюеться наземними 
передавачами, за допомогою кабельного телебачення або супутниками будь-якого типу в кодованому або відкритому вигляді телевізійних чи радіопрограм, що приймаються населенням» [11]. Закон України «Про телекомунікації» (2003р.) встановлює спеціальне правове регулювання для Інтернету; телекомунікацій (електрозв'язку) та телемереж [12].

Так, Закон України «Про інорормацію», що у свій час став джерелом вихідних положень в інформаційній сфрері, визначає ЗМI як засоби, призначені для публічного поширення друкованої або аудіовізуальної інформації. При цьому Закон передбачає поділ ЗМІ на друковані та аудіовізуальні 3МI [13]. Можна дійти до висновку, що законодавець розглядав 3MI, насамперед, як об'єкт, за допомогою якого отримується інформація, тобто як спосіб фріксації та засіб передачі інформації. Разом із тим, тлумачний словник визначає слова «засіб/спосіб», як «якусь спеціальну дію, яка надає змогу здійснювати що-небудь, або те, що слугує знаряддям у будь-якій справі» [14].

На рівні доктрини також відсутні едині підходи до розуміння ЗМI. Г. Штромайер вважає, що для позначення ЗМI варто використовувати термін "мас-медіа", до якого слід відносити: друковані засоби масової інфрормації; аудіовізуальні засоби масової інформації (радіо і телебачення); засоби масової інформації, що працюють в режимі «он-лайн» або інтернет-мультимедійні 3МI [15].

М.А. Федотов визначає ЗМI «як певну форму періодичного поширення масової інфрормації [16]. Водночас Н.М. Ільченко виокремлює декілька підходів визначення ЗМІ - як підприємство, як технологічний засіб, як соціальний інститут, який дає змогу отримувати інформаційний продукт [17].

На думку В.С. Шестак, ЗМІ - це особливий учасник індормащійних відносин, тобто суб'єкт, який створений у формі юридичної особи (організація, інформаційне агентство тощо), що спрямовані на задоволення інформаційних потреб громадян, юридичних осіб та держави (одержання, використання та поширення інформащіi) [18].

О.А. Вознесенська стверджуе, що ЗМI - «це юридична особа, за допомогою якої доводиться інфрормаційна продукція до широкого кола споживачів та задоволення їх індормаційних потреб» [19]. В.А. Аврааменко визначає ЗМI як самостійну організацію, основною фрункцією якої є пошук, отримання, виробництво і розповсюдження індрормації за допомогою періодичних друкованих видань, радіо-, відео-, та інших електронних форорм [20]. У науковій літературі поруч 3 класичним поняттям «засіб масової інфрормації» з'являеться термін «засіб масової комунікації». Якщо ЗМI - це технічні засоби створення, запису, копіювання, тиражування, зберігання і поширення інформації для масової аудиторії, то ЗМК - це технічні засоби створення, запису, копіювання, тиражування, зберігання, поширення сприйняття інформації і обміну нею між суб'єктом та об'єктом. Ми вважаємо, що на сьогодні ці поняття не можна ототожнювати, на відміну, від уподібнення поняття 3MI та масмедіа 3 огляду на наступне.

Комунікація (від лат. Communication - повідомлення, передача) формувалась 3 потреб сус- пільства в колективному існуванні й тому є суспільною за своєю природою. Це контактування одне 3 одним, за допомогою якого люди обмінюються, чужими і власними думками та почуттями, повідомленнями завдяки мові чи іншим знакам. Під терміном «масова комунікація» (від латин. informatio - повідомлення, викладення) тлумачать шляхи розповсюдження інформації, що адресуеться необмеженій кількості соціальних груп, осіб, держав, для того щоб оперативно інформувати їх щодо явищ та подій у світі, конкретних країнах, певних регіонах, та для виконання спеціальних громадських фрункцій [21]. Доцільно виділити кілька основних ознак ЗМК: публічність; наявність відповідних форм передачі інфрормації; наявність відповідної фрорми взаємодії комунікаційних партнерів; односторонній вплив комунікаторів на реципієнтів; мінливий, розсіяний характер своєї аудиторії, який виникає в деяких випадках у результаті суцільної уваги, що проявилася до тих чи інших засобів передачі інформації.

Взаємодія осіб на підставі масової комунікації забезпечує суспільні дії. Соціальна залежність походить від соціальних дій. При цьому соціальному відношенні соціальна система не може виконувати необхідні їй соціальні дії, через те що інша система не виконуе своїх дій.

ЗМI - це інститути та фрорми публічного і відкритого поширення інформащії для широкого кола користувачів, що здійснюється за допомогою технічних засобів.

Вони є складною системою, у якій виділяють два головних типи 3MI: електронні (радіомовлення, телебачення, кінопродукція, аудіопродукція) та друковані (преса). У наш час ЗМI $€$ установами, створеними для публічної, відкритої передачі за допомогою спеціальних технічних інструментів різноманітних відомостей різним особам. Ця відносно самостійна система характеризується багатоукладністю елементів: властивостями, змістом, методами, формами та деякими рівнями організації (у державі, у регіоні, на виробництві). Відмінність ЗМІ - це їхня публічність, а саме безмежне коло користувачів, наявність спеціальної апаратури та технічних приладів; залежно від виявів зацікавленості щодо передач, статей або повідомлень змінюеться й аудиторія.

Саме тому 3МК та 3MI не слід ототожнювати. Перше поняття, а саме ЗМК, характеризуе більш широкий набір масових засобів. До ЗМК можна віднести театр, кіно, цирк та ін., різноманітні вистави, що відзначаються регулярністю проведення у своєму зверненні до масової аудиторії. Також варто віднести до ЗМК технічні масові засоби, такі як телеграфр, телефон, телетайп тощо. Друге поняття, тобто ЗМI, має низку тотожних ознак із ЗМК, що, проте, не робить їх однакими. До того ж ЗМI мають певні ознаки, що в межах розгляду досліджуваного розмежування понять сприймаються як притаманні тільки цьому поняттю. Серед таких ознак варто виділити, наприклад, наявність технічних засобів. Розбіжність в основних напрямах діяльності можна простежити, вивчаючи фрннції зазначених понять.

O.В. Каплій запропонувала визначення «системи 3MI» як «сукупності організацій, що 
розповсюджують на аудіовізуальних, друкованих носіях або за допомогою мережі Інтернет інфрормацію для сприйняття їі невизначеним колом суб'єктів, які здійснюють свою діяльність у правовому полі України, фрункціонування яких відбуваеться на основі різних форм власності з метою пошуку, отримання, виробництва, розповсюдження та доведення до соціальних суб'єктів інформації» [22].

Натомість Р.З. Гусейнова-Чекурда стверджує, що електронні засоби масової інфрормації мають найбільший вплив на формування громадської думки, соціальну та правову поведінку суб'єктів конституційного права - і все це завдяки швидкісній передачі інформації численним користувачам, що вказує на безумовні переваги електронних засобів масової інформації у порівнянні з друкованими [23].

У сучасних умовах неможливо уявити існування і розвиток українського суспільства без електронних 3МI. Характерною рисою масмедіа є здатність прямого зв'язку з громадськістю, при цьому оминаючи застарілі традиційні інститути суспільства, які зазвичай об'єднують його членів (наприклад, сім'я, школа, університет, робота, різноманітні організації та інше). Очевидно, що ця «сила» 3МІ використовуеться у формі рекламного агента, який намагаеться переконати публіку придбати новий товар чи послугу, проголосувати за того чи іншого кандидата, звернути увагу на суспільні проблеми. Дійсно, не можна недооцінювати роль ЗМІ в сучасних політичних процесах, в комунікації суспільства та влади.

Відомо, що комунікація як процес виникає тільки в людському середовищі. Загалом комунікація як суспільний феномен не є метою нашого дослідження, але щоб розуміти місце та роль 3МI у цьму процесі та його особливості в інформаційному суспільстві, вважаємо за необхідне звернутися до наукового визначення комунікації як опосередкованої та цілеспрямованої взаємодії двох суб'єктів. Оскільки в процесі комунікації виникає "опосередкована та/ або цілеспрямована взаємодія», то ЗМІ в цьому процесі можуть бути як впливовими акторами, так і просто посередниками.

Українська дослідниця Н. Костенко об'єднує парадигми підходів до вивчення масової комунікації у тези, які відображають силу або слабкість впливу мас-медіа на ціннісні системи суспільства: 1) засоби масової інформації є всемогутніми і впливовими; 2) мас-медіа, обмежені системою соціальних інститутів, не втрачають своєї автономії, а тому лише частково впливають на свідомість і поведінку людей [24].

Комунікація як двосторонній процес завжди відбувається під впливом зовнішнього середовища. В умовах плюралістичного суспільства та демократизації державного управління доцільно процес комунікації як взаємодію органів держави і ЗМІ представити в більш загальному вигляді, оскільки, крім взаємодії ці два суб'єкти комунікації відчувають на собі різноманітний вплив з боку соціального оточення.

Особливо зростае впливова соціальна роль 3MI в періоди трансорормації політичних режимів, оскільки без їх активної діяльності не- можливо змінити політичну свідомість, ціннісні орієнтації та цілі широкого загалу, а також отримати масову підтримку політики суспільних змін. Зрозуміло, що про ЗМІ як «політичного комунікатора" можна говорити тільки тоді, коли вони перебувають у демократичних умовах або близьких до них - в умовах гласності та прозорості.

У сучасних суспільствах саме через ЗМI, зокрема через новини, людина долучається до події, яка просто не може її оминути. Преса, радіо, телебачення діють не лише як засоби, від яких події зберігають відносну незалежність, а i як сама умова їх існування. При цьому можуть відбуватися важливі події, про які ніхто не знає, оскільки їх не показували по телебаченню. На жаль, суспільство, яке все більше замінює здорову соціальну взаємодію через живе спілкування та безпосередню участь у громадських процесах на штучну та опосередковану участь за допомогою 3MI, стає все більш уразливим до маніпулятивних впливів.

Отже, можемо зробити висновок, що роль і місце 3МI в системі суспільної комунікації $\epsilon$ досить важливими, а в умовах розвитку інформаційного суспільства - дедалі більш визначальними. Переваження у ЗМІ (особливо телебачення) розважального компоненту в боротьбі за глядача створює умови для формування симулякритивної дійсності та маніпулятивної ураженості суспільства. Водночас слід визнати, що 3 розвитком Інтернету як засобу масової інформації, атомізацією суспільства, становлення індивідуалізованої людини вплив 3MI на «формування порядку денного» (дещо знижується, але підвищуеться рівень головної фрункції - інформування. За таких умов зростае роль якості взаємодії органів державної влади і 3MI для підвищення ефрективності інформування суспільства, становлення системи відкритості влади, її підпорядкованості громадським інтересам, демократизації державного управління. Тому необхідно формувати нові підходи щодо взаємодії органів державної влади і ЗМІ з урахуванням вже напрацьованих наукою цивілізованих форм і методів, ПР-засобів та особливостей професійної діяльності ЗМІ в умовах їх економічної незалежності.

Висновки. Підбиваючи підсумки визначенню 3MI, можна виокремити їх особливі риси: публічність, необмеженість та над персональність, кількість споживачів; наявність спеціальних технічних засобів, апаратури для передачі інформації; непряма, поділена у просторі та часі взаємодія комунікаційних партнерів; спрямованість взаємодії від комунікатора до реципієнта та неможливість зміни ролей; непостійний, дисперсний характер аудиторії, яка залучається в результаті загального уявлення до того чи іншого інформаційного повідомлення. Пропонуємо авторське визначення «засобу масової інформаціï» як юридичної особи (організації), діяльність якої спрямована на виробництво і швидкісну передачу інформаційної продукції публічного характеру для необмеженої кількості споживачів, яка фонкщіонуе шляхом створення та розповсюдження будь-яким законним способом донесення інфрормації до споживачів (аудиторії). 


\section{Список літератури:}

1. Конвенція про захист прав людини і основоположних свобод від 04.11.1950. URL: https://zakon.rada.gov.ua/ laws/show/995_004\#Text (дата звернення: 21.10.2020).

2. Статут ООН з питань освіти, науки та культури (ЮНЕСКО) 1945 року. URL: https://zakon.rada.gov.ua/laws/ show/995_014\#Text (дата звернення: 21.10.2020).

3. Резолюция 428 (1970) Относительно декларации о средствах массовой информации и правах человека. URL: http://www.data.minsk.by/books/ce_massmedia/3.html (дата звернення: 21.10.2020).

4. Заключний акт Наради з безпеки та співробітництва в Європі від 01.08.1975 p. URL: https://zakon.rada.gov.ua/ laws/show/994_055\#Text (дата звернення: 21.10.2020).

5. Конвенция о международном праве опровержения (1952 г.). URL: http://www.un.org/ru/documents/decl_conv/ conventions/correct.shtml (дата звернення: 21.10.2020).

6. Рекомендація CM/Rec(2007)15 Комітету Міністрів країнам-членам Ради Свропи щодо висвітлення виборів засобами масової інформації. URL: http://www.medialaw.kiev.ua/laws/laws_international/155/ (дата звернення: 20.10.2020).

7. Рекомендация $\mathrm{CM} / \operatorname{Rec}(2011) 7$ Комитета министров государствам-членам о новом понятии СМИ (Принята Комитетом министров 21 сентября 2011 года на 1121-ом заседании постоянных представителей министров). URL: http://cyberpeace.org.ua/files/ii_e_14.pdf (дата звернення: 20.10.2020).

8. The Mass Media Act. URL: http://www.rtvslo.si/files/razno/mass_media_act.pdf (accessed 10 October 2020).

9. Radio and Television Act. URL: http://www.radioochtv.se/Documents/Styrdokument/Radio\%20and\%20Television \%20Act.pdf?epslanguage $=$ sv (accessed 05 October 2020).

10. Про друковані засоби масової інформації (пресу) в Україні : Закон України від 16.11.1992 № 2782 -XII. Відолості Верховної Ради Украӥни. 1993. № 1. Ст. 1.

11. Про телебачення і радіомовлення : Закон України від 21.12.1993 3759-XII. Відомості Верховної Ради України. 1994. № 10. Ст. 43.

12. Про телекомунікації : Закон України від 18.11.2003 № 1280-IV. Відолості Верховної Ради України. 2004. № 12 . Ст. 155 .

13. Про інформацію : Закон України від 2.10.1992 № 2657-XII. URL: https://zakon.rada.gov.ua/laws/show/2657-12 (дата звернення: 15.10.2020).

14. Великий тлумачний словник сучасної української мови / уклад. і голов. ред. В. Т. Бусел. Київ : Ірпінь: ВТФ «Перун», 2009. 1736 с.

15. Штромайер Г. Політика і мас-медіа / Пер. з нім. А. Орган. Київ : Вид. дім «Киево-Могилянська академія», 2008. 303 с.

16. Федотов М.А. Право массовой информации в Российской Федерации. Москва : Междунар. отнош., 2002.624 с.

17. Ільченко Н.M. Механізми реалізації державної політики у сфері 3МI (регіональний рівень) : авторефр. дис. ... канд. наук з держ. управління : спец. 25.00.02 «Механізми державного управління». Київ, 2008.20 с.

18. Шестак В.С. Засоби масової індормащії та їх роль у суспільстві і державі: питання адміністративно-правового забезпечення. URL: http://www.nbuv.gov.ua/portal/soc_gum/Pib/2010_5/PB-5/PB-5_33.pdf (дата звернення: 15.10.2020)

19. Вознесенська О.А. Правові засади державного регулювання в галузі аудіовізуальних засобів масової інформації : дис. ... канд. юрид. наук : 12.00.01 / Науково-дослідний інститут інформатики і права. Київ, 2012. 215 с.

20. Авраменко В.И. Правовое регулирование деятельности средств массовой информации в современной России: общетеоретический анализ : дис. ... канд. юрид. наук : 12.00.01. Нижний Новгород, 2001.170 с.

21. Пахнін М.Л. Сутність, форми та функції засобів масовоїкомунікації в сучасних умовах. Проблели $і$ перспективи розвитку підприелниитва : зб. наук. пр. Харків : ХНАДУ, 2016. № 3(14). Т. 2. С. 83-88.

22. Каплій О.В. Класифікація засобів масової інформації: конституційно-правові питання. Актуальні проблеми політики. 2013. Вип. 50. С. 35-46.

23. Гусейнова-Чекурда Р.3. Конституційне право людини і громадянина на свободу слова (на прикладі 3МI). Науковий вісник Національної акаделії внутрішніх справ. 2011. № 2(75). С.159-166.

24. Костенко Н. Досвід контент-аналізу: Моделі та практики. Київ : Центр вільної преси, 2003. 200 с.

\section{References:}

1. Konventsiia pro zakhyst prav liudyny i osnovopolozhnykh svobod. URL: https://zakon.rada.gov.ua/laws/ show/995_004\#Text (in Ukrainian)

2. Statut $\bar{O} \overline{O N}$ z pytan osvity, nauky ta kultury (IuNESKO) 1945 roku. URL: https://zakon.rada.gov.ua/laws/ show/995_014\#Text (in Ukrainian)

3. Rezoliutsyia 428 (1970) Otnosytelno deklaratsyy o sredstvakh massovoy ynformatsyy y pravakh cheloveka. URL: http://www.data.minsk.by/books/ce massmedia/3.html (in Russian)

4. Zakliuchnyi akt Narady z bezpeky ta spivrobitnytstva v Yevropi. URL: https://zakon.rada.gov.ua/laws/show/ 994_055\#Text (in Ukrainian)

5. Konventsiya o mejdunarodnom prave oproverjeniya (1952). URL: http://www.un.org/ru/documents/decl_conv/ conventions/correct.shtml (in Russian)

6. Rekomendatsiia CM/Rec(2007)15 Komitetu Ministriv kraïnam-chlenam Rady Yevropy shchodo vysvitlennia vyboriv zasobamy masovoï informatsiï. URL: http://www.medialaw.kiev.ua/laws/laws_international/155/ (in Ukrainian)

7. Rekomendatsiya CM/Rec(2011)7 Komiteta ministrov gosudarstvam-chlenam o novom ponyatii SMI (Prinyata Komitetom ministrov 21 sentyabrya 2011 goda na 1121-om zasedanii postoyannyih predstaviteleĭ ministrov). URL: http://cyberpeace.org.ua/files/ii_e_14.pdf (in Russian)

8. The Mass Media Act. URL: http://www.rtvslo.si/files/razno/mass media act.pdf

9. Radio and Television Act. URL: http://www.radioochtv.se/Documents/Styrdokument/Radio\%20and\%20Television $\% 20$ Act.pdf?epslanguage $=\mathrm{sv}$

10. Pro drukovani zasoby masovoï informatsiï (presu) v Ukraïni. No 2782-XII. No 1. St. 1. (1993). (in Ukrainian)

11. Pro telebachennia i radiomovlennia. No 3759-XII. No 10. St. 43. (1994). (in Ukrainian)

12. Pro telekomunikatsiï . No 1280-IV. No 12. St. 155. (2004). (in Ukrainian)

13. Pro informatsiiu : Zakon Ukrainy vid 2 zhovtnia 1992 roku № 2657- XII. URL: https://zakon.rada.gov.ua/laws/ show/2657-12 (in Ukrainian) 
14. Busel. V.T. (2009) Velykyi tlumachnyi slovnyk suchasnoi ukrainskoi movy / uklad. i holov. red. V.T. Busel. Kyiv: Irpin: VTF «Perun». (in Ukrainian)

15. Shtromay̌ier H. (2008) Polityka i mas-media / Per. z nim. A. Orhan. Kyiv: Vyd. dim «Kyievo-Mohylianska akademiia». (in Ukrainian)

16. Fedotov M.A. (2002) Pravo massovoy informatsii v Rossiyskoy Federatsii. Moscow: Mejdunar. otnosh. (in Russian)

17. Ilchenko N.M. (2008) Mekhanizmy realizatsii derzhavnoi polityky u sferi ZMI (rehionalnyi riven): avtoref. dys. ... kand. nauk z derzh. upravlinnia: spets. 25.00.02 "Mekhanizmy derzhavnoho upravlinnia». Kyiv. (in Ukrainian)

18. Shestak V.S. Zasoby masovoi informatsii ta yikh rol u suspilstvi i derzhavi: pytannia administratyvno-pravovoho zabezpechennia. URL: http://www.nbuv.gov.ua/portal/soc_gum/Pib/2010_5/PB-5/PB-5_33.pdf (in Ukrainian)

19. Voznesenska O.A. (2012) Pravovi zasady derzhavnoho rehuliuvannia $\mathrm{v}$ haluzi audiovizualnykh zasobiv masovoi informatsii: dys. ... kand. yuryd. nauk: 12.00.01 / Naukovo-doslidnyi instytut informatyky i prava. Kyiv. (in Ukrainian)

20. Avramenko V.Y. (2001) Pravovoe rehulyrovanye deiatelnosty sredstv massovoi ynformatsyy v sovremennoi Rossyy: obshcheteoretycheskyi analyz: dys. ... kand. yuryd. nauk: 12.00.01. Nyzhnyi Novhorod. (in Russian)

21. Pakhnin M.L. (2016) Sutnist, formy ta funktsii zasobiv masovoikomunikatsii v suchasnykh umovakh. Problemy $i$ perspektyvy rozuytku pidpryiemnytstva: zb. nauk. pr. Kharkiv: KhNADU, 3. (in Ukrainian)

22. Kaplii O.V. (2013) Klasyfikatsiia zasobiv masovoi informatsii: konstytutsiino-pravovi pytannia. Aktualni problemy polityky, 50. (in Ukrainian)

23. Huseinova-Chekurda R.Z. (2011) Konstytutsiine pravo liudyny i hromadianyna na svobodu slova (na prykladi ZMI). Naukovyi visnyk Natsionalnoi akademii vnutrishnikh sprav, 2(75). (in Ukrainian)

24. Kostenko N. (2003). Dosvid kontent-analizu: Modeli ta praktyky. Kyiv: Tsentr vilnoi presy. (in Ukrainian) 